\title{
RESPONSE SURFACE METHODOLOGY APPROACH FOR OPTIMIZATION OF METHYL ORANGE ADSORPTIVE REMOVAL BY MAGNETIC CHITOSAN NANOCOMPOSITE
}

\author{
Bahareh Tanhaei $^{1}$, Ali Zeraatkar Moghaddam ${ }^{2}$, Ali Ayati ${ }^{1}$, Fatemeh Deymeh ${ }^{3}$, Mika Sillanpää ${ }^{4}$ \\ ${ }^{1}$ Department of Chemical Engineering, Quchan University of Advanced Technology, Quchan, Iran \\ ${ }^{2}$ Department of Chemistry, Faculty of Science, University of Birjand, Birjand, South Khorasan, Iran \\ ${ }^{3}$ Department of Chemical Engineering, Faculty of Engineering, Birjand University of Technology, \\ Birjand, South Khorasan, Iran \\ ${ }^{4}$ Laboratory of Green Chemistry, LUT School of Engineering Science, \\ Lappeenranta University of Technology, Sammonkatu 12, FI-50130 Mikkeli, Finland
}

a.ayati@qiet.ac.ir; ayati_a_ali@yahoo.com

In this work, the adsorption process of methyl orange (MO) removal by a magnetic chitosan with an $\mathrm{Al}_{2} \mathrm{O}_{3} / \mathrm{Fe}_{3} \mathrm{O}_{4}$ core was optimized using the experimental design method in order to maximize the removal efficiency. Response surface methodology (RSM) based on central composite design (CCD) was performed to find the relationship between the effective adsorption parameters on the MO removal efficiency as the response. The statistical parameters of the derived model were acquired: $R^{2}=0.9799$ and $F$ value $=47.07$. Finally, non-linear optimization was carried out and values of $6.5,0.70 \mathrm{~g} \mathrm{l}^{-1}, 30 \mathrm{ppm}$, and $60 \mathrm{~min}$ were obtained as the optimum values for $\mathrm{pH}$, adsorbent dosage, initial concentration, and contact time, respectively, while the predicted MO removal efficiency was found to be $96.8 \pm 2.2 \%$ (with a $95 \%$ confidence level). This was in agreement with the experimental response of $96.5 \pm 1.4 \%$.

Keywords: adsorption; optimization; chitosan; magnetic; response surface methodology

\section{ПРИМЕНА НА МЕТОДОЛОГИЈАТА НА ПОВРШИНА НА ОДГОВОР ПРИ ОПТИМИЗАЦИЈА НА АТСОРПТИВНО ОТСТРАНУВАЊЕ НА МЕТИЛ ОРАНЖ СО НАНОКОМПОЗИТ ОД МАГНЕТИЗИРАН ХИТОСАН}

Во ова истражување, со примена на методот на експериментален дизајн, беше оптимизиран атсорпцискиот процес на отстранување на метил оранж (МO) со магнетизиран хитозан со јадро од $\mathrm{Al}_{2} \mathrm{O}_{3} / \mathrm{Fe}_{3} \mathrm{O}_{4}$ за да се максимизира ефикасноста на отстранувањето. Беше применета методологијата на површината на одговор (RSM) заснована на централен копмпозитен дизајн (CCD) за да се најде зависноста меѓу ефективните атсорпциски параметри за ефикасноста на отстранувањето на MO како одговор. Беа добиени статистички параметри изведени од моделот $\mathrm{R}^{2}=0,9799$ и вредноста $\mathrm{F}$ $=47,07$. На крајот, беше извршена нелинеарна оптимизадција и беа добиени следниве соодветни оптимални вредности за $\mathrm{pH}$, доза на атсорбенсот, почетна концентрација и време на контакт од $6,5,0,70 \mathrm{~g} \mathrm{l}^{-1}, 30 \mathrm{ppm}$ и $60 \mathrm{~min}$, соодветно, додека предвидената ефикасност на отстранување изнесуваше $96,8 \pm 2,2 \%$ (со 95\% ниво на веродостојност) што беше во согласност со експериментално добиената вредност од $96,5 \pm 1,4 \%$.

Клучни зборови: атсорпција; оптимизација; хитозан; магнетски својства; методологија на површина на одговор 


\section{INTRODUCTION}

Chitosan (poly-(1-4)-2-amino-2-deoxy-b-dglucose) is the second most abundant natural biopolymer and is produced from $N$-deacetylation of chitin [1]. The intrinsic characteristics of chitosan, such as its availability, non-toxicity, biocompatibility, and reactivity, make it a widely used material in the chemical, environmental, pharmaceutical, food, and medical fields [2,3]. Chitosan and its derivatives are among the most low cost and plentiful biopolymer adsorbents and have attracted significant interest for the removal of organic and inorganic pollutants from waste water [4-10] due to their outstanding chelating behavior $[11,12]$.

A drawback of chitosan-based adsorbents that may lead to the blocking of filters, loss of adsorbents, or generation of secondary pollution is related to their separation and regeneration from aqueous solution using traditional separation techniques such as sedimentation and filtration [13]. To overcome this problem, recent research has focused on magnetic chitosan composites to apply magnetic separation technology $[9,14]$. The magnetic separation technique is low cost, rapid, convenient, and amenable to automated methods [15, 16], and the magnetic composites can be easily separated from the medium by a simple magnetic field [13, 17].

Although extensive research has been done on magnetic chitosan based composites $[13,18$ 21], in the majority of these studies, the effect of different parameters such as adsorbent dosage, sample $\mathrm{pH}$, contact time and pollutant concentration on the pollutant removal percentage or adsorption capacity of adsorbent is investigated. Despite the numerous studies, no definite relationship between these parameters and their interactions to achieve the highest adsorption capacity/removal efficiency. Actually, it seems that optimization of the process is more important and practical in adsorption studies.

Several statistical methodologies have been used for optimizing the process variables such as the Taguchi methods, genetic algorithm, neural network, iterative mathematical search technique, metaheuristic search technique, heuristic search technique, simulated annealing [21-23], and response surface methodology (RSM) [24]. RSM is a statistical method that applies quantitative data from appropriate experiments to solve multivariate equations in order to obtain the optimal conditions for achieving the best response. Central composite design (CCD) is the most popular method of mak- ing a second-order RSM in process optimization. It is a good alternative to full factorial design to obtain more data with a lower experimental number. In contrast to other methods, CCD uses axial points and therefore needs two more experiments for each parameter at the highest and lowest levels [25]. The CCD method involves three steps: (i) designing the experiments, (ii) estimating the coefficients in a mathematical model, and (iii) predicting the response and the model validation.

Dyes are a class of pollutants present in the waste water of the textile, pulp, leather and metal industries and their decomposition into carcinogenic aromatic amines under anaerobic conditions can have serious harmful effects on living organisms [26-28]. Thus, their elimination has become a major concern in recent years $[29,30]$. In this study, we applied the experimental design as a highly efficient optimization method to optimize the adsorption process for the removal of methyl orange (MO), as a model anionic dye, using a recently introduced magnetic chitosan based core-shell material (chitosan $/ \mathrm{Al}_{2} \mathrm{O}_{3} / \mathrm{Fe}_{3} \mathrm{O}_{4}, \mathrm{Cs}-\mathrm{AF}$ ) [20].

We investigated the interaction between the parameters and optimal conditions using limited experiments, and the RSM was employed to find a reliable predictive model under CCD.

\section{MATERIALS AND METHODS}

\subsection{Chemicals and instruments}

The used chitosan was purchased from Acros Organics, and all other chemicals applied for the synthesis of Cs-AF, namely iron oxide nanopowder $(50-100 \mathrm{~nm}, \geq 98 \%)$, glutaraldehyde solution (25\%), and aluminum isopropoxide $(\geq$ $98 \%$ ) as well as MO, were obtained from Sigma Aldrich Co.

The MO azo dye concentrations (C) were measured using the Beer-Lambert law, in which the absorbance value $\left(\lambda_{\max }=464 \mathrm{~nm}\right)$ was obtained using a JASCO V-670 spectrophotometer (Japan).

The Cs-AF nano-adsorbent was prepared according to the method reported in our previous work [20] and a scanning electron microscopy (SEM) image of prepared adsorbent is shown in Figure 1. The Brunauer-Emmett-Teller (BET) surface area of Cs-AF was measured as $22.07 \mathrm{~m}^{2} / \mathrm{g}$ and the adsorption and desorption cumulative pore volumes were reported as 0.0218 and 0.0224 $\mathrm{cm}^{3} / \mathrm{g}$, respectively, using Barret-Joyner-Halenda $(\mathrm{BJH})$ analysis [20]. 


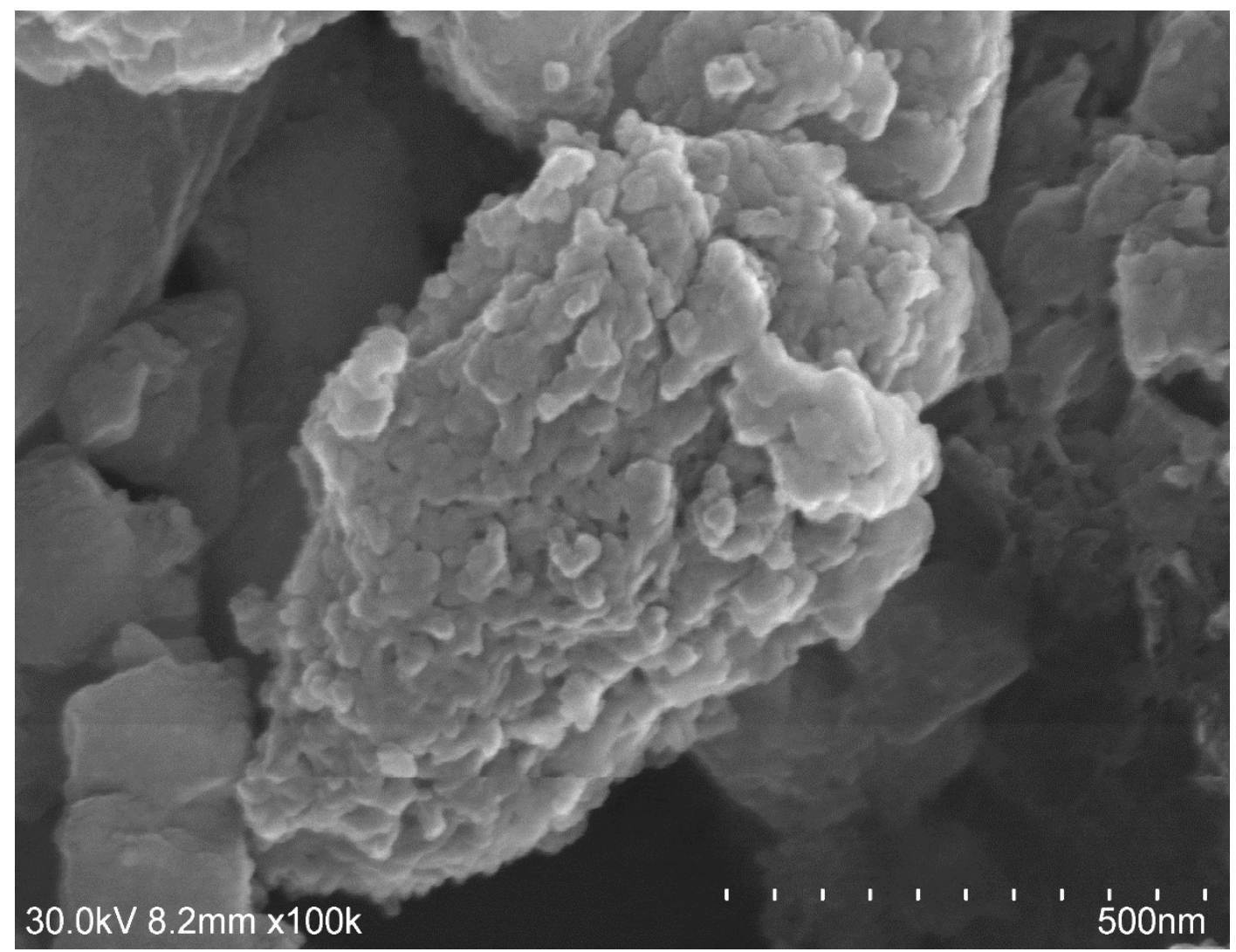

Fig. 1. SEM image of prepared Cs-AF

\subsection{Batch adsorption experiments}

For the adsorption experiments, the desired amount of Cs-AF adsorbent was added to $10 \mathrm{ml}$ of MO solution in a $15 \mathrm{ml}$ tube on a Lab Treatment ST5 CAT shaker. After a specific time interval, the solution was filtered using a $0.45 \mu \mathrm{m}$ syringe filter and analyzed for residual $\mathrm{MO}$ concentration. The MO removal percentage (R, \%) and MO adsorption capacity $\left(\mathrm{Q}, \mathrm{mg} \mathrm{g}^{-1}\right)$, were calculated by the following equations respectively:

$$
\begin{aligned}
\mathrm{R}(\%) & =\frac{C_{0}-C_{t}}{C_{0}} \times 100 \\
\mathrm{Q} & =\frac{C_{0}-C_{t}}{m} V
\end{aligned}
$$

where $C_{0}$ and $C_{t}\left(\mathrm{mg} \mathrm{l}^{-1}\right)$ are the MO concentrations at the initial time and time $t$, respectively; $m$ (g) is the adsorbent amount; and $V(\mathrm{l})$ is the solution volume.

\subsection{Software}

The trial version of the software package Design-Expert 8 (Minneapolis, USA) was employed for the design of experiment.

\section{RESULTS AND DISCUSSION}

\subsection{Experimental design}

Univariate methodology is still used as a conventional method in optimization procedures, but it requires a large experimental run, which is time consuming, costly and, especially, does not consider interactions between variables. The multivariate techniques are fast, effective, and provide optimization of more than one variable simultaneously [31-33]. CCD, as a type of RSM method, is an independent, rotatable, orthogonal and quadratic design [24].

Despite the various variables that affect the dye removal efficiency using the proposed adsorbent, four parameters - namely $\mathrm{pH}$, adsorbent dosage, initial dye concentration and contact time were found to be the most important variables based on our previous study [20]. In the present work, the influence of these variables on the MO removal efficiency, as the response, was evaluated by CCD. Then, the effects of the variables on the response, which contributed to the building of a surface, were considered by RSM, and the graphical relationship between these variables and the response was obtained based on the mathematical 
modeling of the MO-removal efficiency. Finally, analysis of variance (ANOVA) was applied to evaluate the model and analyze the data.

\subsection{Model development by CCD}

Due to the small number of factors, there is no need for screening of the factors by factorial design, so CCD, which was first presented by Box and Wilson [34], was used directly. Generally, a CCD approach for $k$ factors, coded as $\left(\chi_{1}, \ldots, \chi_{k}\right)$, includes three parts: (i) a factorial design, formed by a total of $n_{\mathrm{f}}=2^{\mathrm{k}}$ points with the coordinates of $\chi_{\mathrm{i}}=-1$ or $\chi_{\mathrm{i}}=+1$, for $\mathrm{i}=1, \ldots, k$; (ii) an axial part, containing $n_{\mathrm{ax}}=2 k$ points with all their coordinates null, excluding the point with a certain value of $\alpha$ (or $-\alpha$ ), ranging from 1 to $\sqrt{k}_{k}$; (iii) a total of $n_{c}$ runs at the center of the experimental region to at- tain some properties such as orthogonality or rotatability to fit quadratic polynomials. In order to get a good estimate of experimental error, the center points are usually repeated. A CCD is made rotatable and orthogonal by the choice of a suitable axial point, $\alpha$ [34].

For the $f$ number of variables, the number of needed design points $(N)$ can be obtained using Eq. (3):

$$
N=2^{f}+2 f+N_{0} .
$$

Therefore, 30 experiments had to be performed for the CCD design in the studied case. They were randomized in two blocks for the same reasons as mentioned in the factorial design section. The appropriate ranges for the factors were defined based on our recent study [20] (Table 1).

Table 1

Factors, factor notation, and their levels in CCD

\begin{tabular}{ccccccc}
\hline \hline Factor & \multirow{2}{*}{ Notation } & \multicolumn{5}{c}{ Levels } \\
\cline { 5 - 7 } & & $-\boldsymbol{\alpha}^{\mathbf{a}}$ & $\mathbf{- 1}$ & $\mathbf{0}$ & $\mathbf{+ 1}$ & $+\boldsymbol{\alpha}$ \\
\hline CCD & $\mathrm{A}$ & 1.5 & 4 & 6.5 & 9 & 11.5 \\
Sample pH & $\mathrm{B}$ & 0.1 & 0.4 & 0.7 & 1.0 & 1.3 \\
Adsorbent dose $\left(\mathrm{mg} \cdot \mathrm{ml}^{-1}\right)$ & $\mathrm{C}$ & 10 & 20 & 30 & 40 & 50 \\
Initial dye concentration (ppm) & $\mathrm{D}$ & 0 & 30 & 60 & 90 & 120 \\
Contact time (min) & & & & & &
\end{tabular}

${ }^{\mathrm{a}}$ For this rotatable $\mathrm{CCD}$, the axial distance is 2.0 .

Table 2

Analysis of variance (ANOVA) for CCD

\begin{tabular}{cccccc}
\hline \hline Source & $\begin{array}{c}\text { Sum of } \\
\text { squares }\end{array}$ & $\begin{array}{c}\text { Degree of } \\
\text { freedom }\end{array}$ & $\begin{array}{c}\text { Mean } \\
\text { square }\end{array}$ & F value & $\begin{array}{c}\text { p-value } \\
\text { Prob > F }\end{array}$ \\
\hline Model & $2.1 \times 10^{+12}$ & 14 & $1.5 \times 10^{+11}$ & 47.07 & $<0.0001^{\mathrm{s}}$ \\
$\mathbf{A}$ & $4.5 \times 10^{+8}$ & 1 & $4.5 \times 10^{+8}$ & 0.14 & $0.7165^{\mathrm{ns}}$ \\
$\mathbf{B}$ & $7.6 \times 10^{+11}$ & 1 & $7.6 \times 10^{+11}$ & 235.70 & $<0.0001^{\mathrm{s}}$ \\
$\mathbf{C}$ & $1.3 \times 10^{+10}$ & 1 & $1.3 \times 10^{+10}$ & 4.00 & $0.0708^{\mathrm{ns}}$ \\
$\mathbf{D}$ & $3.2 \times 10^{+6}$ & 1 & $3.2 \times 10^{+6}$ & 0.001 & $0.9752^{\mathrm{ns}}$ \\
$\mathbf{A B}$ & $2.4 \times 10^{+9}$ & 1 & $2.4 \times 10^{+9}$ & 0.75 & $0.4052^{\mathrm{ns}}$ \\
$\mathbf{A C}$ & $2.7 \times 10^{+9}$ & 1 & $2.7 \times 10^{+9}$ & 0.83 & $0.3808^{\mathrm{ns}}$ \\
$\mathbf{A D}$ & $1.4 \times 10^{+9}$ & 1 & $1.4 \times 10^{+9}$ & 0.44 & $0.5181^{\mathrm{ns}}$ \\
$\mathbf{B C}$ & $1.6 \times 10^{+10}$ & 1 & $1.6 \times 10^{+10}$ & 5.13 & $0.0446^{\mathrm{s}}$ \\
$\mathbf{B D}$ & $8.5 \times 10^{+10}$ & 1 & $8.5 \times 10^{+10}$ & 26.36 & $0.0003^{\mathrm{s}}$ \\
$\mathbf{C D}$ & $1.3 \times 10^{+9}$ & 1 & $1.3 \times 10^{+9}$ & 0.4143 & $0.5330^{\mathrm{ns}}$ \\
$\mathbf{A}^{\mathbf{2}}$ & $7.4 \times 10^{+11}$ & 1 & $7.4 \times 10^{+11}$ & 229.45 & $<0.0001^{\mathrm{s}}$ \\
$\mathbf{B}^{\mathbf{2}}$ & $1.1 \times 10^{+11}$ & 1 & $1.1 \times 10^{+11}$ & 33.82 & $0.0001^{\mathrm{s}}$ \\
$\mathbf{C}^{\mathbf{2}}$ & $1.0 \times 10^{+5}$ & 1 & $1.0 \times 10^{+5}$ & $3.2 \times 10^{-5}$ & $0.9956^{\mathrm{ns}}$ \\
$\mathbf{D}^{\mathbf{2}}$ & $1.6 \times 10^{+10}$ & 1 & $1.6 \times 10^{+10}$ & 5.06 & $0.0458^{\mathrm{s}}$ \\
Residual & $3.5 \times 10^{+10}$ & 11 & $3.2 \times 10^{+9}$ & & \\
Lack of fit & $3.2 \times 10^{+10}$ & 8 & $4.0 \times 10^{+9}$ & 3.32 & $0.1762^{\mathrm{ns}}$ \\
Pure error & $3.6 \times 10^{+9}$ & 3 & $1.2 \times 10^{+9}$ & & \\
Cor total & $2.4 \times 10^{+12}$ & 27 & & & \\
\hline \hline
\end{tabular}

s: significant

ns: not significant 
Firstly, the values of the responses were transformed to the power of three values for $\mathrm{MO}$ removal efficiency (not shown) according to the Box-Cox plot. The ANOVA table for the CCD design matrix is shown in Table 2 and can be used to select a suitable RSM, the significances of the model equation, and the model terms. As can be seen in Table 2, the F-value is 47.07, indicating that the model is significant. Also, a value of "Prob $>\mathrm{F}^{\prime \prime}$ less than 0.050 for a factor indicates the significance of its effect. Based on higher F- and Rvalues and also lower lack of fit (LOF) and the prediction-error sum of squares (PRESS), a quadratic RSM was selected to fit the experimental data. The regression coefficients' values were calculated via the multiple linear regression (MLR) model, in backward mode, to exclude nonsignificant effects from the model. Accordingly, the predictive model for the MO removal percentage using Cs-AF adsorbent in terms of the coded factors can be presented by the following equation:

$$
\begin{gathered}
\text { Removal }(\%)=+879407.5+208376.6 \mathrm{~B}- \\
22585.1 \mathrm{C}+32121.2 \mathrm{BC}-36391.0 \mathrm{BD}- \\
214909.0 \mathrm{~A}^{2}-82612.6 \mathrm{~B}^{2}-80.0 \mathrm{C}^{2}+ \\
26790.4 \mathrm{D}^{2}
\end{gathered}
$$

The F-value of 3.32 obtained for LOF indicates that there is no significant relation to the pure experimental error and confirms the validity of the predicted model. Other statistical parameters of the predicted model for the adsorptive removal of MO over Cs-AF are listed in Table 3. The coefficient of variation $(\mathrm{CV})$ of $1.41 \%$ and standard deviation of 1.37 are reasonably low. Also, a low value of 0.30 is found for PRESS, calculated by Eq. (5):

$$
\operatorname{PRESS}=\sum_{i=1}^{n}\left(e_{i,-i}\right)^{2} \quad e_{i,-i}=y_{i}-\hat{y}_{i,-i}
$$

where $e_{i, i}, y_{i}$, and $\hat{y}_{i,-i}$ are the residual, the experimental value and the predicted value, respectively. The $R$-squared parameter, as a measure of variation around the mean value, was evaluated as 0.9799 for the model, and is defined as follows:

$$
R^{2}=1-\frac{S S_{\text {resid }}}{S S_{\text {model }}+S S_{\text {resid }}}
$$

where $S S_{\text {resid }}$ and $S S_{\text {model }}$ are the residual sum of squares and model sum of squares, respectively.
Table 3

Statistical parameters

for the quadratic model in Eq. (4)

\begin{tabular}{lcll}
\hline \hline $\begin{array}{l}\text { Adequacy } \\
\text { precision }\end{array}$ & 32.58 & $\boldsymbol{R}$-squared & 0.9799 \\
CV \% & 1.41 & Predicted $\boldsymbol{R}$-squared & 0.9721 \\
PRESS & 0.30 & Adjusted $\boldsymbol{R}$-squared & 0.9558 \\
\hline \hline
\end{tabular}

The quality of the fit of the model is expressed by the adjusted $R^{2}\left(R_{\text {adj }}^{2}\right)$ and predicted $R^{2}$ $\left(R_{\text {pred }}^{2}\right)$ in Eqs. (7) and (8), respectively, and they should be within 0.20 of each other $[24,35]$.

$$
\begin{gathered}
R_{\text {adj }}^{2}=1-\frac{n-1}{n-p}\left(\frac{S S_{\text {Error }}}{S S_{\text {total }}}\right)=1-\frac{(n-1)}{(n-p)}\left(1-R^{2}\right) \\
R_{\text {adj }}^{2}=1-\left(\frac{\text { PRESS }}{S S_{\text {total }}-S S_{\text {block }}}\right)
\end{gathered}
$$

In these equations, $n$ is the number of experiments and $p$ is the number of model parameters including the intercept and any block coefficient. The $R_{\text {pred }}^{2}$ and $R_{\text {adj }}^{2}$ values for the above model for the MO removal percentage onto Cs-AF were found to be 0.9721 and 0.9558 , respectively.

The statistical significance was checked using the adequate precision ratio, presented in Eqs. (9) and (10) [36].

$$
\begin{gathered}
\text { adequate precision }=\left[\frac{\max (\bar{y})-\min (\bar{y})}{\sqrt{\bar{V}(\bar{y})}}\right] \\
\bar{V}(\bar{y})=\frac{1}{n} \sum_{i=1}^{n} \bar{V}(\bar{y})=\frac{p \sigma^{2}}{n}
\end{gathered}
$$

where $\bar{y}, p$, and $n$ are the predicted value, the number of model parameters, and the number of experiments, respectively, and $\sigma^{2}$ is the residual mean square from the ANOVA table. As can be seen in Table 3 , the adequate precision was found to be 32.58 (> 4.0), indicating the model adequacy.

The normal probability and studentized residuals plot for the MO removal efficiency by Cs$\mathrm{AF}$ are shown in Figure 2a. In this figure, the points follow a straight line, indicating that the residuals follow a normal distribution. Moreover, checking the plots of residuals versus different variables such as predicted values, run order, and factors (not shown) showed a nearly constant variance over the variable ranges. 

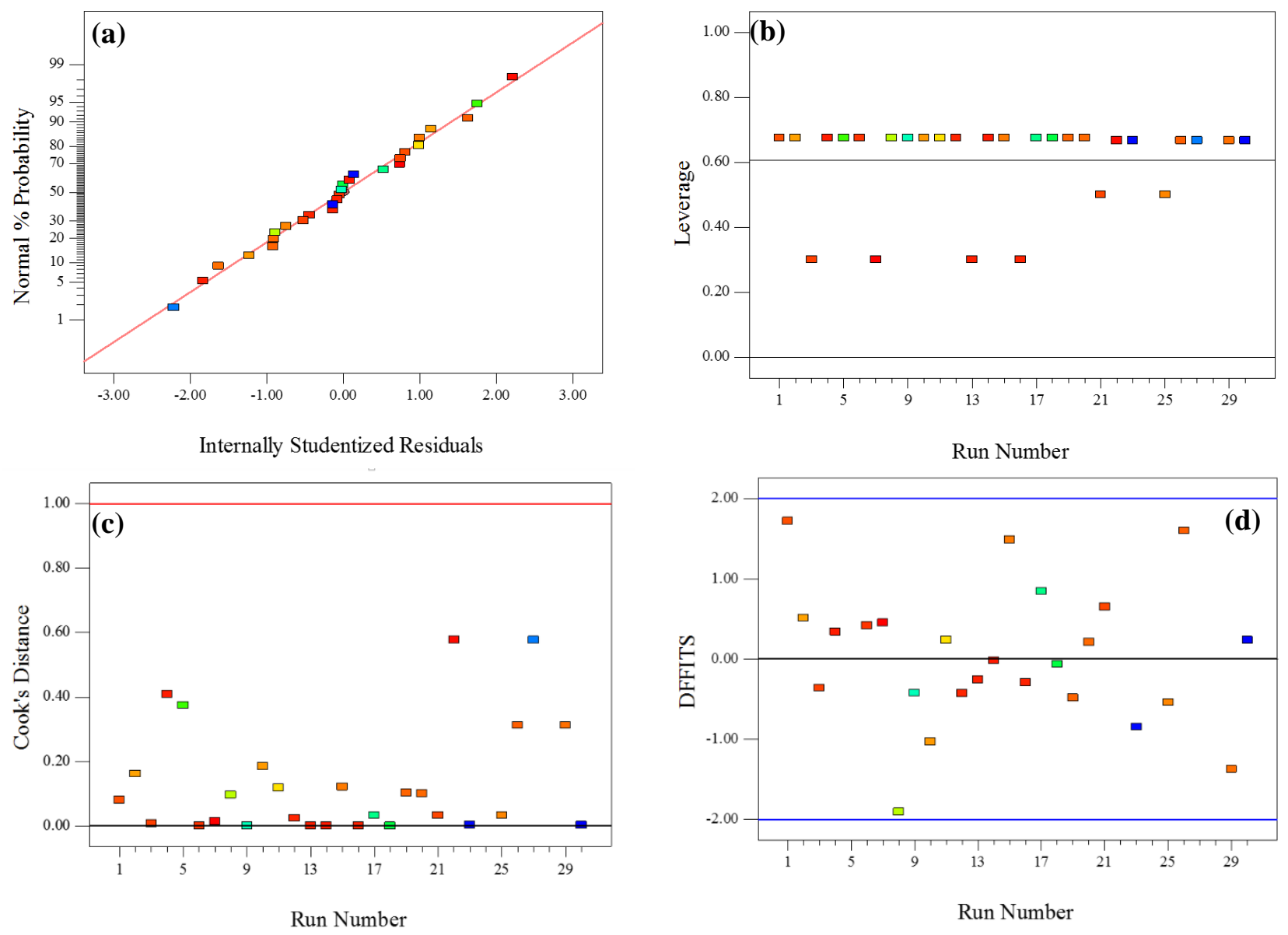

Fig. 2. a) Normal probability plot of studentized residuals, b) leverage plot, c) Cook's distance plot, d) difference in fits (DFFITS) plot for evaluating the suggested quadratic model for MO removal efficiency.

For further evaluation of the model, the leverage, Cook's distance, and difference in fits (DFFITS) plots [24] are studied and the results are shown in Figs. 2b-d. Leverage [24] is a measure of how each point influences the model fit. A high leverage point represents an unexpected error in a data point that strongly influenced the model. As can be seen in Fig. 2b, all the leverage values are lower than 0.8 , showing that there is no unexpected error or outliers in the model. Also, the Cook's distance (Fig. 2c) and DFFITS (Fig. 2d) plots confirmed this result. The Cook's distance (Fig. 2c) [24] is a measure of how the regression changes if the case is deleted, and the DFFITS (Fig. 2d) [24] is a measure of each point's influence on the predicted value. In all these figures, the values are in the determined range (red line in Figs. $2 b-d$ ) and verify the reliability of the model.

In order to study the interpretation of interactions, three-dimensional plots of the model are highly recommended [24, 37]. It is very useful to visualize the relationship between the responses and the studied effective factors. Figure 3 shows the plots of the response model versus two experi- mental factors at fixed values of other factors at their central levels. Figure 3a represents the effect of solution $\mathrm{pH}$ and adsorbent dosage. It clearly shows that the adsorbent dosage has positive effects on the removal of MO whereas the removal efficiency increased with increases in the sample $\mathrm{pH}$ until about $\mathrm{pH}$ 6-7 and then decreased. This is in agreement with the reported results of our recent study [20]. As can be seen in Figure 3a, the lines are not parallel, which indicates that there is no interaction between adsorbent dosage and sample $\mathrm{pH}$. The response surface plot for the effect of sample $\mathrm{pH}$ and initial concentration on the removal efficiency is shown in Figure 3b. It demonstrates that when the initial concentration was decreased, the removal efficiency increased. In this case, there is also no interaction between $\mathrm{pH}$ and initial concentration or between the sample $\mathrm{pH}$ and contact time (see Fig. 3c) in the adsorptive removal of MO by Cs-AF. As can be seen in Figure 3c, the removal efficiency was increased by increasing the contact time and there is no interaction between these factors either. Similarly, there is no interaction between the adsorbent dosage and contact time (see 
Fig. 3d). The trends in Figures $3 \mathrm{e}$ and $3 \mathrm{f}$ show that there is an interaction between adsorbent dosage and initial concentration as well as between adsor- bent dosage and contact time. Due to the interactions between these factors, there is no linear relation between the response and factors. (a)

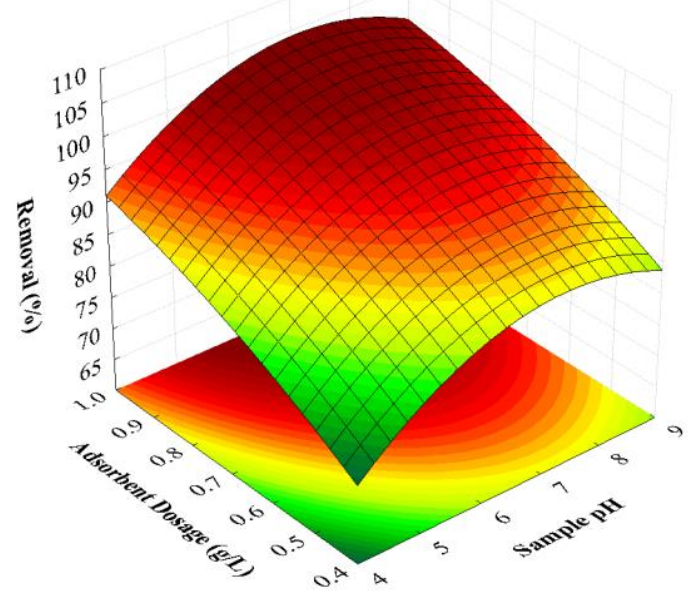

(c)

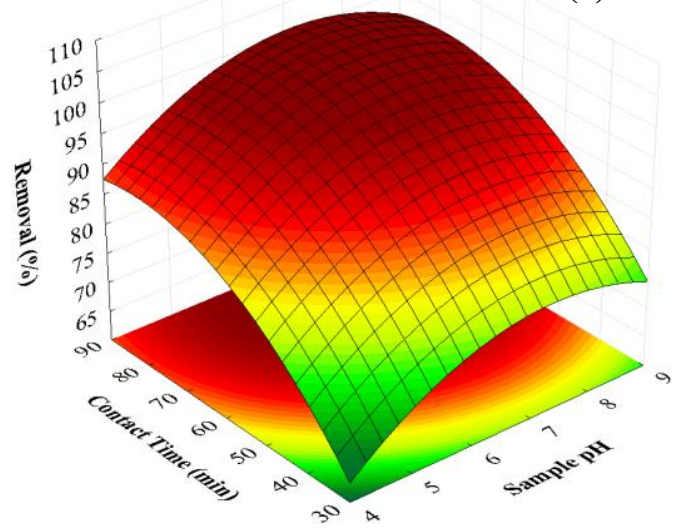

(e)

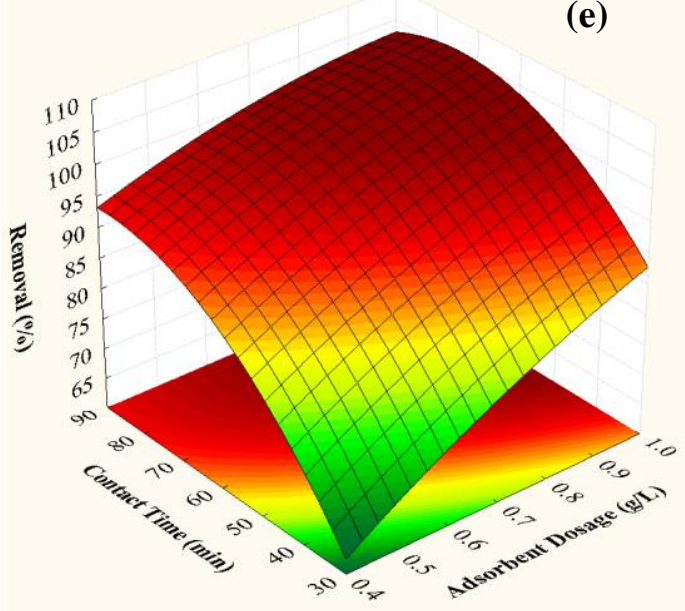

(b)
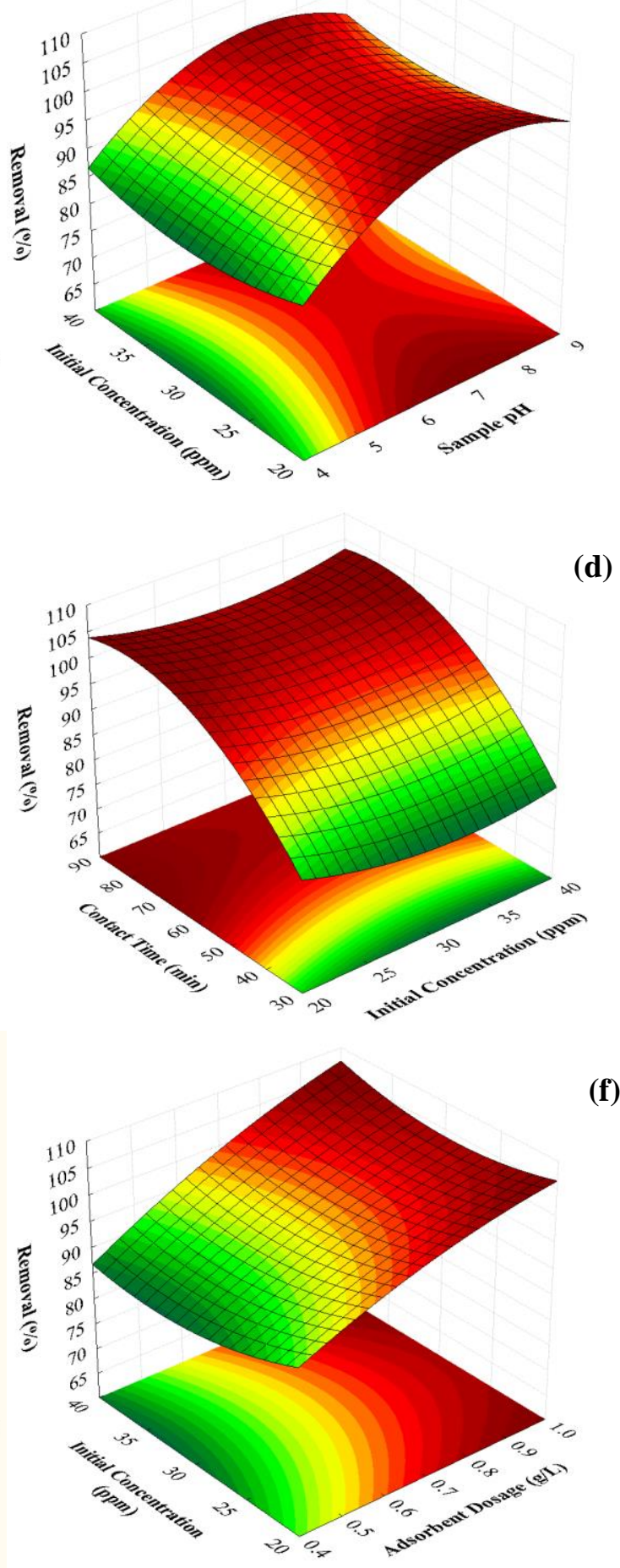

(f)

Fig. 3. The response surface plots of the effect of sample $\mathrm{pH}$, adsorbent dose, initial dye concentration, and contact time. (a) Sample pH (A) - Adsorbent dose (B); (b) Sample pH (A) - Initial dye concentration (C); (c) Sample pH (A) - Contact time (D); (d) Adsorbent dose (B) - Initial dye concentration (C); (e) Adsorbent dose (B) - Contact time (D); (f) Initial dye concentration (C) - Contact time (D). 


\subsection{Non-linear optimization}

Finding the optimum values of effective factors to maximize the MO removal efficiency onto Cs-AF from the obtained model is the main objective of the optimization, which was carried out using the trial version of Design-Expert 8.0.0 software. According to the non-linear optimization method, the optimum values of the variables sample $\mathrm{pH}$, adsorbent dosage, and contact time were found to be $6.5,0.70 \mathrm{~g} \mathrm{l}^{-1}$ and $60 \mathrm{~min}$, respectively, to achieve the maximum values of removal efficiency and initial concentration (30 ppm). With a 95\% confidence level, the optimum predicted response was found to be $96.8 \pm 2.2 \%$. This was verified by performing the experiments under the optimized conditions, in which the experimental MO removal efficiency was found to be $96.5 \pm 1.4 \%$, in close agreement with the CCD model predictions.

\section{CONCLUSIONS}

The statistical experimental design methodology was used for the optimization of MO dye adsorption from aqueous solution using Cs-AF in order to maximize the removal efficiency. Inspection of the RSM demonstrates that the initial concentration of MO has a negative effect on the response (removal efficiency) versus the positive effect of adsorbent dosage and contact time. A quadratic model was proposed by CCD and was found to be in good agreement with the experimental data $\left(R^{2}=0.9799\right)$. Also, the optimum conditions for an initial MO dye concentration of 30 $\mathrm{ppm}$ were found to be a $\mathrm{pH}$ of 6.5 , contact time of $60 \mathrm{~min}$, and adsorbent dosage of $0.7 \mathrm{~g} \mathrm{l}^{-1}$, which gave a removal efficiency of $96.8 \%$, in close agreement with the CCD model predictions.

Acknowledgments. This work was supported by Quchan University of Advanced Technology under grant number 11198.

\section{REFERENCES}

[1] C. Liu, R. Bai, Recent advances in chitosan and its derivatives as adsorbents for removal of pollutants from water and wastewater. Curr. Opin. Chem. Eng., 4, 62-70 (2014).

[2] A. Bhatnagar, M. Sillanpää, Applications of chitin- and chitosan-derivatives for the detoxification of water and wastewater - A short review. Adv. Colloid Interface Sci., 152, 26-38 (2009).

[3] H. Sashiwa, S. Aiba, Chemically modified chitin and chitosan as biomaterials. Prog. Polym. Sci., 29, 887-908 (2004).
[4] E. Repo, J. K. Warchoł, A. Bhatnagar, A. Mudhoo, M. Sillanpää, Aminopolycarboxylic acid functionalized adsorbents for heavy metals removal from water. Water Res., 47, 4812-4832 (2013).

[5] E. Repo, J. K. Warchol, T. A. Kurniawan, M. Sillanpää, Adsorption of $\mathrm{Co}(\mathrm{II})$ and $\mathrm{Ni}(\mathrm{II})$ by EDTA- and/or DTPA-modified chitosan: kinetic and equilibrium modeling. Chem. Eng. J., 161, 73-82 (2010).

[6] N. M. Alves, J. F. Mano, Chitosan derivatives obtained by chemical modifications for biomedical and environmental applications. Int. J. Biol. Macromol., 43, 401414 (2008).

[7] W. S. W. Ngah, S. A. Ghani, A. Kamari, Adsorption behavior of $\mathrm{Fe}(\mathrm{II})$ and $\mathrm{Fe}(\mathrm{III})$ ions in aqueous solution on chitosan and cross-linked chitosan beads. Bioresource Technol., 96, 443-450 (2005).

[8] M. Vakili, M. Rafatullah, B. Salamatinia, A. Z. Abdullah, M. H. Ibrahim, K. B. Tan, Z. Gholami, P. Amouzgar, Application of chitosan and its derivatives as adsorbents for dye removal from water and wastewater: A review. Carbohyd. Polym., 113, 115-130 (2014).

[9] A. Ayati, B. Tanhaei, M. Sillanpää, Lead(II)-ion removal by ethylenediaminetetraacetic acid ligand functionalized magnetic chitosan-aluminum oxide-iron oxide nanoadsorbents and microadsorbents: Equilibrium, kinetics, and thermodynamics. J. Appl. Polym. Sci., 134, 44360 (2016).

[10] B. Tanhaei, A. Ayati, F. F. Bamoharram, M. Lahtinen, M. Sillanpää, A novel magnetic Preyssler acid grafted chitosan nano adsorbent: synthesis, characterization and adsorption activity. J. Chem. Technol. Biotechnol., 91, 1452-1460 (2016).

[11] G. Crini, P. M. Badot, Application of chitosan, a natural aminopolysaccharide, for dye removal from aqueous solutions by adsorption processes using batch studies: A review of recent literature. Prog. Polymer Sci, , 33, 399447 (2008).

[12] F. Zhao, E. Repo, D. Yin, M. E. T. Sillanpää, Adsorption of $\mathrm{Cd}(\mathrm{II})$ and $\mathrm{Pb}(\mathrm{II})$ by a novel EGTA-modified chitosan material: Kinetics and isotherms. J. Colloid Interf. Sci., 409, 174-182 (2013).

[13] D. H. K. Reddy, S. M. Lee, Application of magnetic chitosan composites for the removal of toxic metal and dyes from aqueous solutions. Adv. Colloid Interface Sci., 201-202, 68-93 (2013).

[14] B. V. S. Reddy, G. Narasimhulu, P. S. Lakshumma, Y. V. Reddy, J. S. Yadav, Phosphomolybdic acid: a highly efficient solid acid catalyst for the synthesis of trans-4,5disubstituted cyclopentenones. Tetrahedron Lett., 53, 1776-1779 (2012).

[15] A. M. Donia, A. A. Atia, K. Z. Elwakeel, Selective separation of mercury(II) using magnetic chitosan resin modified with Schiff's base derived from thiourea and glutaraldehyde. J. Hazard. Mater., 151, 372-379 (2008).

[16] R. D. Ambashta, M. Sillanpää, Water purification using magnetic assistance: A review. J. Hazard. Mater., 180, 38-49 (2010).

[17] R. Hua, Z. Li, Sulfhydryl functionalized hydrogel with magnetism: Synthesis, characterization, and adsorption 
behavior study for heavy metal removal. Chem. Eng. J., 249, 189-200 (2014).

[18] W. S. W. Ngah, L. C. Teong, M. A. K. M. Hanafiah, Adsorption of dyes and heavy metal ions by chitosan composites: a review. Carbohydr. Polym., 83, 14461456 (2011).

[19] E. Repo, J. K. Warchoł, A. Bhatnagar, M. Sillanpää, Heavy metals adsorption by novel EDTA-modified chitosan-silica hybrid materials. J. Colloid Interface Sci., 358, 261-267 (2011).

[20] B. Tanhaei, A. Ayati, M. Lahtinen, M. Sillanpää, Preparation and Characterization of a Novel Chitosan/ $\mathrm{Al}_{2} \mathrm{O}_{3} /$ Magnetite Nanoparticles Composite Adsorbent for Kinetic, Thermodynamic and Isotherm Studies of Methyl Orange Adsorption. Chem. Eng. J., 259, 1-10 (2015).

[21] B. Tanhaei, A. Ayati, M. Lahtinen, B. M. Vaziri, M. Sillanpää, A magnetic mesoporous chitosan based coreshells biopolymer for anionic dye adsorption: kinetic and isothermal study and application of ANN. J. Appl. Polym. Sci. ,133, 43466 (2016).

[22] N. Sivarajasekar, R. Baskar, Adsorption of basic red 9 on activated waste Gossypium hirsutum seeds: Process modeling, analysis and optimization using statistical design. J. Ind. Eng. Chem., 20, 2699-2709 (2013).

[23] G. Derringer, R. Suich, Simultaneous optimization of several response variables. J. Quality Technol., 12, 214 219 (1980)

[24] D. C. Montgomery, Design and Analysis of Experiments. John Wiley, 2000.

[25] D. O. Aksoy, E. Sagol, Application of central composite design method to coal flotation: Modelling, optimization and verification. Fuel, 183, 609-616 (2016).

[26] N. Sivarajasekar, R. Baskar, Agriculture waste biomass valorisation for cationic dyes sequestration: A concise review. J. Chem. Pharm. Res. 7, 737-748 (2015).

[27] N. Sivarajasekar, R. Baskar, Biosorption of basic violet 10 onto activated Gossypium hirsutum seeds: Batch and fixed-bed column studies. 23, 1610-1619 (2015).

[28] N. Sivarajasekar, R. Baskar, Adsorption of Basic Magenta II onto $\mathrm{H}_{2} \mathrm{SO}_{4}$ activated immature Gossypium hir- sutum seeds: Kinetics, isotherms, mass transfer, thermodynamics and process design. Arab. J. Chem., In Press, (2014).

[29] A. Ayati, A. Ahmadpour, F. F. Bamoharram, M. Mänttäri, M. Sillanpää, A review on Catalytic Applications of Au Nanoparticles in the Removal of Water Pollutant. Chemosphere, 107, 163-174 (2014).

[30] A. Ayati, M. N. Shahrak, B. Tanhaei, M. Sillanpää, Emerging adsorptive removal of azo dye by metalorganic frameworks. Chemosphere, 160, 30-44 (2016).

[31] G. Khoobbakht, G. Najafi, M. Karimi, A. Akram, Optimization of operating factors and blended levels of diesel, biodiesel and ethanol fuels to minimize exhaust emissions of diesel engine using response surface methodology. Appl. Thermal Eng., 99, 1006-1017 (2016).

[32] V. Srivastava, Y. C. Sharma, M. Sillanpää, Application of response surface methodology for optimization of Co(II) removal from synthetic wastewater by adsorption on $\mathrm{NiO}$ nanoparticles. J. Mol. Liq., 211, 613-620 (2015).

[33] V. Srivastava, Y. C. Sharma, M. Sillanpää, Response surface methodological approach for the optimization of adsorption process in the removal of $\mathrm{Cr}(\mathrm{VI})$ ions by $\mathrm{Cu}_{2}(\mathrm{OH})_{2} \mathrm{CO}_{3}$ nanoparticles. Appl. Surf. Sci., 326, 257270 (2015).

[34] E. Morgan, Chemometrics: Experimental Design. London: Wiley, 1991.

[35] M. Jalali-Heravi, H. Parastar, H. Ebrahimi-Najafabadi, Characterization of volatile components of Iranian saffron using factorial-based response surface modeling of ultrasonic extraction combined with gas chromatography -mass spectrometry analysis. J. Chromatogr. A, 1216, 6088-6097 (2009).

[36] B. K. Korbahti, M. A. Rauf, Determination of optimum operating conditions of carmine decoloration by $\mathrm{UV} / \mathrm{H}_{2} \mathrm{O}_{2}$ using response surface methodology. J. Hazard. Mater., 161, 281-286 (2009).

[37] R. L. Mason, R. F. Gunst, J. J. Hess, Statistical Design and Analysis of Experiments with Applications to Engineering and Science. Hoboken: Wiley, 2003. 
